\title{
Design of Composite Shear Wall Encased with Vertical Steel Profiles
}

\author{
P. P. Phadnis ${ }^{1}$, V. V. Karjinni ${ }^{2}$ \\ ${ }^{1}$ Shivaji University, Kolhapur, Maharashtra, India. \\ ${ }^{2}$ Kolhapur Institute of Technology's College of Engineering, Kolhapur, Maharashtra, India. \\ ${ }^{1}$ Email: ppp_tech@unishivaji.ac.in
}

ARTICLE INFORMATION

DOI: $10.15415 /$ jotitt.2019.71004

Keywords: Steel-concrete composite shear wall, Reinforced concrete shear wall, Boundary elements, Shear connectors

\begin{abstract}
The concept of steel-concrete composite shear wall is introduced due to the benefits achieved by integrating both the materials. These are structural walls, where steel profiles are encased at the boundary elements. Due to their higher lateral strength and stiffness, they offer a good alternative to improve earthquake resistance over conventional reinforced concrete shear walls in medium and high-rise buildings. Current literature shows that, design procedure of such composite shear walls is not addressed in developing country codes. Hence, a design of steel-concrete composite shear wall is proposed in the present paper on the basis of existing theory and with the help of standard codes. The web portion of shear wall has to be designed as per provisions of Eurocode 8. For the design of composite boundary elements, design norms of composite columns are followed. Also the design of shear stud connectors is adopted according to Eurocode 4.
\end{abstract}

\section{Introduction}

The consequences of the earthquake may lead to the loss of life and property. Reinforced Concrete Shear Walls (RCSW) have been used in building structures for many years. The purpose behind the same is to resist typical lateral load generated due to natural causes like severe wind and earthquake. In the last four decades, many researchers have been performed analytical and experimental investigations of different types of shear wall to realize the actual seismic behavior. A new hybrid frame-wall system has been proposed by Shirali (2002) consisting of the concrete filled tube or rectangular section serving as edge member columns and reinforced concrete shear wall [1]. He further demonstrated an important aspect of the design of hybrid wall system is interface connection between edge columns and concrete shear wall according to Eurocode 8 (EC8) Part 3 [2] and USA Uniform Building Code (UBC94) [3]. The behavior and the adequacy of dual plate composite shear wall during an earthquake have been investigated [4] and the design of shear wall explained according to ASCE 7 (2010) [5] and AISC (2010) [6]. Post earthquake behavior has illustrated that significant damage has still occurred in RCSW due to a lack of confinement 
of the concrete core and bulking of the longitudinal steel in edge elements [7]. This may result in deterioration in strength and stiffness, splitting and ultimately wall failure. To avoid such adverse situation, the Eurocode 8 (Part 1) [8] recommended providing boundary elements concentrated with vertical reinforcement and closely spaced ties, at both extremities of RCSW [8]. However, even with such provision, when the wall thickness is below $300 \mathrm{~mm}$, these boundary elements result in the congested reinforcement [9]. Steel plate shear walls have also been used as a lateral load resisting systems in mid-rise and tall buildings. The provision of steel shear wall may lead to major disadvantage like decrease in shear strength, stiffness and energy dissipation capability due to the buckling of compression region [10]. To overcome this difficulty, a new steel-concrete composite shear wall (SCCMSW) has been intended. In SCCMSW large amount of reinforcement in boundary elements is replaced by steel profiles [11, 12]. SCCMSW offer higher strength and deformation capability and prevent buckling of steel elements due to presence of confined concrete by stirrups [13].

The design of steel-concrete composite columns embedded with single steel profile subjected to both axial compression and uni-axial/bi-axial bending using recommendations of $\mathrm{EC}_{4}$ [14] has been illustrated [15]. The database for composite columns, beam-columns, circular and rectangular tubes filled with concrete has been presented specified by current design provision [16]. The design of composite columns encased by W-shapes in concrete has been elaborated as prescribed by AISC LFRD manual $[17,18]$. An innovative shear wall system has been proposed consisting of concrete filled steel tube column and concealed steel trusses to improve seismic response of the structure [19]. AISC Manual illustrated design procedure for columns with inserted steel shapes such as W-shape, composite filled rectangular or square HSS bent, filled round HSS bent subjected to combine axial force and flexure [20]. The critical appraisal of literature survey has shown that, reinforced concrete composite sections encased with more than one steel section are not addressed in usual design codes and need further elaboration.

The objective of the present paper is to present design aspects of newly proposed SCCMSW on the basis of existing theory and available standard codes. The equivalent lateral load procedure specified by EC8 [8] has been used to analyze and design the structure. The details of the wall panels and boundary elements of SCCMSW have been elaborated. Also, the design of shear stud connectors at interface connection between steel sections and concrete has been briefly discussed.

\section{Design considerations}

As the current design standards have not yet specified design procedures of proposed SCCMSW, the procedures prescribed by EC8 [8] for RCSW have been followed. For, the design of composite boundary elements, design norms of a composite column (EC8) [8] have to be used. The design of shear stud connectors at interface connection between steel sections and concrete to develop full interaction has to be designed according to $\mathrm{EC} 2$ [21]. The Eurocode involves the following steps in the design of the building:

1. Evaluation of base shear considering seismic zone, the earthquake design spectrum and fundamental period of vibration and ductility of structural system

2. Evaluation of the dynamic forces 
through height of the structure by assuming triangular distribution of forces

3. Determination of element forces of building by combining vertical gravity loads and horizontal seismic loads

4. Determination of cross sections and detailing of the elements and connections by taking into account critical load combinations and moments.

\section{Design procedure}

The design procedure for steel-concrete composite walls encased with steel profiles at boundary elements of the wall is explained in following steps:

\subsection{Factored forces as per load combina- tions}

Load combinations considered as per EC 2 [21] are Eq. (1) and Eq. (2)

$1.35 \mathrm{DL}+1.5 \mathrm{LL}$

$\mathrm{DL}+0.3 \mathrm{LL}+\mathrm{EQx}$

3.2 Design of web of wall

3.2.1 Ductile wall special provision for slender wall

The design shear force $V_{E d}[8]$ should be derived in accordance with the expression Eq. (3),

$V_{E d}=\varepsilon \cdot V_{E d}$

where, $V_{E d}$ is the shear force from the analysis $\varepsilon$ is the magnification factor [8] expressed in Eq. (4),

$\varepsilon=q \cdot \sqrt{\left(\frac{\gamma_{R d}}{q} \cdot \frac{M_{R D}}{M_{E d}}\right)^{2}+0.1\left(\frac{S_{e}\left(T_{c}\right)}{S_{e}\left(T_{1}\right)}\right)^{2}} \leq q$

$V_{R d}$ is a global factor, intended to counterbalance the chosen partial safety factor of steel to cover partial hardening effects as well as uncertainties of the model involved; it may be taken as 1.25 of a high ductility class design,
$M_{E d}$ is the design bending moment at the base of the wall,

$M_{R d}$ is the design flexural resistance at the base of the wall,

$S_{e}(T)$ is the ordinate of elastic response spectrum,

$T_{1}$ is the fundamental period of vibration of the building,

$T_{c}$ is the upper limit period of the constant spectral acceleration,

$q$ is the behavior factor,

For composite walls with encased steel profiles, for Ductility Class High (DCH) behavior factor [8] is obtained from Eq. (5),

$q=4 \frac{\alpha_{u}}{\alpha_{1}}$

For composite structural systems, the default value may be taken as or obtained from nonlinear static analysis but not greater than 1.6. [8]

where,

$\alpha_{1}$ is the multiplier of horizontal design seismic action at formation of first plastic hinge in the system

$\alpha_{u}$ is the multiplier of horizontal design seismic action at formation of global plastic mechanism

From (EC8), values of parameter describing the recommended Type 1 elastic response spectra, for soil type C, $S=1.15, T_{B}(S)=0.2$, $T_{C}(S)=0.6$ and $T_{D}=2.0, T=0.4999 .[8]$

Damping correction factor, $\eta[8]$ expressed by Eq. (6)

For $T_{B} \leq T \leq T_{C}$;

$\eta=\sqrt{\frac{10}{(5+\xi)}}$

The response spectrum, $\mathrm{S}_{\mathrm{e}}[8]$, given by Eq. (7),

$S_{e}(T)=a_{g} \cdot s \cdot \eta \cdot 2.5$ 
From response spectrum (EC8) [8] the relation can be obtained as displayed in Eq. (8),

\section{$\frac{S_{e}\left(T_{c}\right)}{S_{e}\left(T_{1}\right)}$}

\subsubsection{Detailing for local ductility of web}

Premature web shear cracking of wall shall be prevented, $\rho_{h, \min }=\rho_{v, \min }=0.002$.

The web reinforcement should be provided in the form of two grids (curtains) of bars with the same bond characteristics, one at the each face of wall. The grids should be connected by cross ties spaced at about 500mm. [8]

\subsubsection{Vertical bars:}

Web reinforcement diameter should not be less than $8 \mathrm{~mm}$ and should not be greater than $1 / 8^{\text {th }}$ times thickness of web. [8]

Spacing of bars should not be more than $250 \mathrm{~mm}$ and 25 times diameter of vertical bar.

$\rho_{v}$ is the reinforcement ratio of vertical web bars [8] determined by Eq. (9).

$\rho_{v}=\frac{A_{v}}{b_{w 0} \times \text { spacing }} \geq 0.002$

\subsubsection{Horizontal bars}

$\rho_{h}$ is the reinforcement ratio of horizontal web bars [8] determined by Eq. (10).

$\rho_{h}=\frac{A_{h}}{b_{w 0} \times \text { spacing }} \geq 0.002$

\subsubsection{Check for Diagonal Tension Failure}

Shear ratio, $\alpha_{\mathrm{s}}$ specified by EC8 [8] is computed from Eq. (11),

$$
\alpha_{s}=\frac{M_{E d}}{V_{E D} l_{W}}<2
$$

For $\alpha_{s}<2$, following provision indicated in Eq. (12) may apply as per EC8 [8]

$$
V_{E d} \leq V_{R d, c}+0.75 \rho_{h} f_{y d, h} b_{w o} \alpha_{s} l_{w}
$$

$f_{y d, h}$ is the design value of the yield strength of horizontal web reinforcement $=360.87 \mathrm{~N} /$ $\mathrm{mm}^{2}$

$V_{R d, c}$ is the value of the shear resistance for members without shear reinforcement accordance.

EC2 [21] is computed with the help of

Eq. (13).

$$
\begin{aligned}
& V_{R d, c}=\left[C_{R d, c} \eta_{1} k\left(100 \rho . \mathrm{f}_{c k}\right)^{1 / 3}+k_{1} \sigma_{c p}\right] b_{w w} d \geq \\
& \left(\eta_{1} v_{1 \text { min }}+k_{1} \sigma_{c p}\right) b_{w} d
\end{aligned}
$$

In the critical region of the wall $V_{R d, c}$ [21] should be equal to zero if axial force $N_{E D}$ is tensile.

The coefficient resulting from experimental results $C_{R d, c}$, [8] from Eq. (14).

$C_{R d, c}=(0.15 / \mathrm{V})$

The value of $v_{\min }$ is computed w.r.t. Eq. (15) [8]

$v_{\text {min }}=0.028 k^{3 / 2} f_{c k}^{1 / 2}$

The coefficient $k_{l}$, with specified as 0.15 [8] is shown in Eq. (16)

$k_{1}=0.15$

The factor $\eta_{1}[8]$ is the only difference with relation to normal density concrete as per Eq. (17)

$\mathrm{n}_{1}=0.4+\frac{0.6 \rho}{2200}$

$\sigma_{c p}$ is mean compressive stress [21] due to axial load, is obtained by using Eq. (18)

$\sigma_{c p}=\frac{\text { Total axial load }}{\text { cross sectional area }}$

But, $\sigma_{c p}<0.2 f_{c d}$

\subsubsection{Check for compression failure of web}

The design shear force $V_{E d}[8]$ shall satisfy the condition described by Eq. (20).

$V_{E d} \leq V_{R d, \max }$

$V_{R d, \max }$ is the design estimate of maximum 
shear force that can be resisted by the element, restricted by crushing of compression struts [8] is given by Eq. (21) and Eq.(22)

For critical zone,

$V_{R d, \max }=0.4\left(0.7-\frac{f_{c k}}{200}\right) f_{c d} b_{w 0} Z$

For the zone outside of the critical region,

$V_{R d, \max }=0.5\left(0.7-\frac{f_{c k}}{200}\right) f_{c d} b_{w 0} Z$

\subsubsection{Check for sliding shear failure of web}

At potential sliding shear planes, (e.g. at construction joints) within critical regions of the of the following condition shall be satisfied given in Eq. (23) [8]

$V_{E d} \leq V_{R d, s}$

where, $V_{R d, s}$ is the design value shear resistance against sliding [8], presented in Eq. (24).

$V_{R d, s}=V_{d d}+V_{i d}+V_{f d}$

With dowel resistance of the vertical bars $V_{d d}$ [8] is minimum of the following represented in Eq. (25) and Eq. (26)

$V_{d d}=1.3 \sum A_{\text {sj }} \sqrt{f_{c d} f_{y d}}$

$V_{d d}=0.25 \mathrm{f}_{\mathrm{yd}} \sum \mathrm{A}_{\mathrm{sj}}$

Shear resistance of inclined bars $V_{i d}[8]$ is provided in Eq. (27).

$V_{i d}=\sum \mathrm{A}_{\mathrm{si}} \mathrm{f}_{\mathrm{yd}} \cos \varphi$

Friction resistance $V_{f d}[8]$ is minimum of the following Eq. (28) and Eq. (29)

$V_{f d}=\mu_{f}\left[\left(\sum A_{s j} f_{y d}+N_{E d}\right) \xi+M_{E d} / z\right]$

$V_{f d}=0.5 \cdot \eta \cdot f_{c d} \cdot \xi \cdot l_{w} \cdot b_{w 0}$

Where,

$\mu_{f}$ is the concrete to concrete friction coefficient under cyclic actions, which may be assumed equal to 0.6 for smooth interfaces and to 0.7 for rough ones defined by EC2: 2004 [21] $z$ is the length of internal lever arm

$\xi$ is the normalized N.A. depth

$\sum A_{s j}$ is the sum of areas of vertical bars of web and additional bars arranged in the boundary elements especially for resistance against sliding.

$\sum A_{s i}$ is the sum of areas of inclined bars in both directions; large diameter bars are recommended for this purpose.

Factor of reduction for compressive strength $\eta[8]$ of concrete because of tensile strain in transverse direction is estimated by Eq. (30).

$$
\eta=0.6 \frac{\left(1-f_{c k}\right)}{250}
$$

$\mathrm{N}_{\mathrm{Ed}}$ is assumed to be positive when compressive.

The length of internal lever arm, $z[8]$ is computed using Eq. (31),

$z=0.8 l_{w}$

Depth of Neutral axis for composite section is evaluated with reference to EC8 [8] by using Eq. (32),

Depth of Neutral axis $=\frac{A_{c} f_{c d}-A_{s r}^{\prime}\left(2 f_{f r}-f_{c d}\right)-A_{s}\left(2 f_{y d}-I_{c d}\right)}{2 h_{c f} f_{c d}}$

Normalized N.A. depth is obtained from Eq. (33),

$\xi=\frac{\text { Depth of Neutral axis }}{\text { Effective Depth }}$

The sum of areas of vertical bars of web and extra bars placed in the boundary elements especially for resistance across sliding is obtained from Eq. (34) where, $n$ is no. of longitudinal rebars and $d$ is diameter of vertical bars.

$A_{s j}=n \times \frac{\pi}{4} \times d^{2}$

\subsection{Design of boundary elements}

The composite shear walls with fully encased structural steel sections used as boundary elements shall be designed according to EC8 [8]. 


\subsubsection{Vertical reinforcement}

EC 4 prescribed that, the longitudinal reinforcement of encased steel section boundary element should not be less than $0.3 \%$ of the cross-section of concrete [14].

$\mathrm{A}_{\mathrm{s}}>0.3 \% \mathrm{~A}_{\mathrm{c}}$

Where,

$\mathrm{A}_{\mathrm{s}}=$ Area of reinforcement in boundary element,

$\mathrm{A}_{\mathrm{a}}=$ area of structural steel profile,

$\mathrm{A}_{\mathrm{c}}=$ Cross sectional area of boundary element concrete $=\mathrm{A}_{\mathrm{g}}-\mathrm{A}_{\mathrm{s}}-\mathrm{A}_{\mathrm{a}}$,

$A_{\mathrm{g}}=$ Gross cross sectional area of section

\subsubsection{Hoop reinforcement}

The diameter of hoops, $d_{b w}[8]$ should be maximum of two values presented Eq. (36)

$d_{w}=\max \left[0.35 \times d_{b L, \max } \times\left(\frac{f_{y a t}}{T_{\text {ydw }}}\right)^{0.5}, 6\right]$ for DCH

In which $d_{b L}=$ maximum diameter of dowel bars and $f_{y d l}$ and $f_{y d w}$ are design strength of flange and reinforcement respectively.

The hoops diameter, $d_{b w}[8]$ of confining ties to prevent flange buckling should not be less than two values presented Eq. (37)

$$
d_{b w}=\left[\left(\frac{b \cdot t_{f}}{8}\right) \cdot\left(\frac{f_{y d l}}{f_{y d w}}\right)\right]^{0.5}
$$

Where, $b$ and $t_{f}$ are width and thickness of flange

Spacing should be minimum of $\left(b_{0} / 2,175\right.$, $\left.8 \times d_{b L}\right)$

\subsubsection{Check for plastic rotation}

To satisfy plastic rotation demands and to compensate for the loss of resistance due to spalling of cover concrete following expression should be satisfied within critical regions [8] expressed in Eq. (38).

$\alpha \cdot \omega_{w d} \geq 30 . \mu_{\emptyset} \cdot v_{d} \cdot \varepsilon_{s y \cdot d} \cdot \frac{b_{c}}{b_{0}}-0.035$
In which the normalized design axial force [8] is defined as Eq. (39).

$v_{d}=\frac{N_{E d}}{N_{p l, R d}}=\frac{N_{E d}}{\left(A_{a} f_{y d}+A_{c} f_{c d}+A_{s} f_{s d}\right)}$

$\omega_{\text {zud }}$ is mechanical volumetric ratio of confining hoops in critical zones [8] is shown in Eq. (40).

$\omega_{w d}=\frac{\text { volume of confining hoops }}{\text { volumeof concrete core }} \times \frac{f_{y d}}{f_{c d}}$

$\omega_{w d}$ should satisfy the condition as indicated in Eq. (41)

But, $\omega_{w d, \text { minimum }} \geq 0.8$

$\mu_{\sigma}$ is required volume of curvature ductility factor [8] presented by Eq. (42) and Eq.(43) for two different conditions.

$\mu_{ø}=2 q_{0}-1$ for $\left(T_{1} \geq T_{c}\right)$

$\mu_{\emptyset}=1+2\left(q_{0}-1\right) \cdot \frac{T_{c}}{T_{1}}$ for $\left(T_{l}<T_{c}\right)$

$b_{c}$ is the cross section depth

$b_{o}$ is the width of confined core (C/L of hoop) $\varepsilon_{\text {sy,d }}$ is the design magnitude of tensile steel strain at yield

$\alpha$ is the confinement effectiveness factor obtained by using (Eq. (44) to Eq. (46))

$\alpha=\alpha_{n} \cdot \alpha_{s}$

$\alpha_{n}=1-\sum_{n} \frac{b_{i}^{2}}{6 b_{0} h_{0}}$

$\alpha_{s}=\left(1-\frac{s}{2 b_{0}}\right)\left(1-\frac{s}{2 h_{0}}\right)$

Where,

$n$ is total no. of longitudinal bars laterally engaged by hoops or cross ties and

$b_{i}$ is the distance between consecutive engaged bars

$h_{0}$ is depth of confined core (to C/L of hoop) 3.3.4 Encased steel profile

The steel contribution ratio $\delta_{1}[14]$ should 
satisfy the condition indicated in Eq. (47)

$0.2 \leq \delta_{1} \leq 0.9$

As recommended by $\mathrm{EC} 4$ [14], $\delta_{1}$ is determined with the help of Eq. (48)

$\delta_{1}=\frac{A_{a} f_{y d}}{N_{P l, R d}}=\frac{A_{a} f_{y d}}{\left(A_{a} f_{y d}+A_{c} f_{c d}+A_{s} f_{s d}\right)}$

\subsection{Design resistance of headed stud shear connector}

Shear connectors are designed for complementary shear induced due to earthquake loads.

Height of the headed stud shear connector, ' $h$ ' should not be less than 3 times diameter of shank.

Head diameter should not be less than 1.5 times diameter of shank.

Diameter of stud should not be greater than 1.5 times the thickness of the plate.

EC4 [14] estimates the resistance as the minimum of two failure modes as expressed in Eq. (49) and Eq. (50).

3.4.1 Failure in the shank of headed stud

$P_{R d}=\frac{0.8 f_{u} \pi d^{2} / 4}{\gamma_{v}}$

3.4.2 Failure in concrete

$P_{R d}=\frac{0.29 \alpha d^{2} \sqrt{f_{c k} E_{c m}}}{\gamma_{v}}$

Where,

$\alpha=0.2\left(\frac{h_{s c}}{d}+1\right)$ for $3 \leq h_{s c} / d \leq 4$

$\alpha=1$ for $h_{s c} / d>4$

where,

$V_{v}$ is the partial factor for design shear resistance of a headed stud shear connector,

$\mathrm{Y}_{v}=1.25$

$d$ is diameter of the shank of the stud, $16 \mathrm{~mm}$ $\leq d \leq 25 \mathrm{~mm}$,

$f_{u}$ is the specified ultimate strength of the material of the stud but not greater than
$500 \mathrm{~N} / \mathrm{mm}^{2}$,

$f_{c k}$ is the characteristic cylinder compressive strength of the concrete at the age considered,

$h_{s c}$ is the overall nominal height of the stud,

$E_{c m}$ is the secant modulus of elasticity of concrete as specified by Eq. (53),

$\left(E_{c m}=0.85 E_{c}=0.85 \times 5000 \times \sqrt{ } f_{c k}\right)$

Longitudinal shear force, $\tau$ [22] can be obtained using Eq. (54)

$\tau=\frac{\mathrm{VA}_{\mathrm{c}} \mathrm{Y}}{\mathrm{I}}$

Where,

$\tau$ is the longitudinal shear per unit length at the interface in the section under consideration,

$V$ is the vertical shear due to loads acting on composite section,

$\Upsilon$ is the distance of N.A. of the composite section to the centriod of the area under consideration,

$I$ is M.I. of the whole transformed area composite section.

Number of shear connectors required [14] is determined by using Eq. (55)

No. of shear connector $=\frac{\tau}{P_{R d, \min }}$

\section{Case study of building}

The composite shear wall with encased steel sections is of length $3 \mathrm{~m}$ and thickness $230 \mathrm{~mm}$ as situated in $2 \mathrm{D}$ frame shown in Fig. 1. Depth of the slab is $120 \mathrm{~mm}$. Dead load of terrace water proofing and floor finish is taken as $1.5 \mathrm{kN} / \mathrm{m}^{2}$ and $0.5 \mathrm{kN} / \mathrm{m}^{2}$ respectively. Imposed load intensity on all floors except roof has been considered as $4 \mathrm{kN} / \mathrm{m}^{2}$ and on the roof is $2 \mathrm{kN} / \mathrm{m}^{2}$. Fig. 1 (a) shows a plan of the building. Fig. 1 (b) shows the sectional elevations of the middle frame with SCCMSW. 


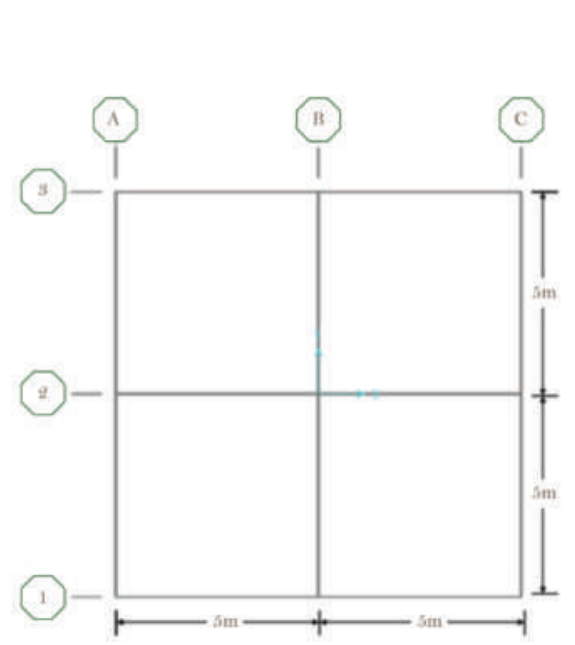

a) Plan of building

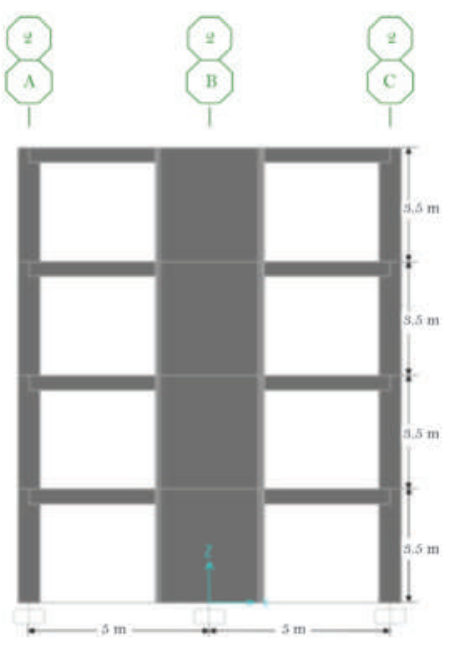

b) Middle frame with SCCMSW

Figure 1: Details of frame-SCCMSW system

Materials used are $M 20$ concrete, Fe415 rebar and Fe41O structural steel. It is subjected to the forces as presented in Table 1.
Design is performed as previously discussed in Section III and obtained results are presented in Table 2.

Table 1: Forces and moments

\begin{tabular}{|l|l|l|l|}
\hline Loading & Axial Force $(\mathbf{k N})$ & Moment $(\mathbf{k N m})$ & $\begin{array}{l}\text { Shear Force } \\
(\mathbf{k N})\end{array}$ \\
\hline DL & 1136.42 & - & - \\
\hline LL & 350.05 & - & - \\
\hline EQx & - & 2262.27 & 239.99 \\
\hline
\end{tabular}

Table 2: Design details

\begin{tabular}{|l|l|l|}
\hline Sr. No. & Design Details & \multicolumn{2}{l|}{ Remarks } \\
\hline A. & Load Combinations & Eq. (1) and (2) \\
\hline & $\begin{array}{l}1.35 \mathrm{DL}+1.5 \mathrm{LL}=2059.25 \mathrm{kN} \\
\text { DL+0.3LL+EQx }=1931.68 \mathrm{kN}\end{array}$ & Eq. (4) satisfied. \\
\hline B. & Ductile wall special provision for slender wall & \begin{tabular}{l}
$\mid$ \\
\hline
\end{tabular} \\
\hline & $\begin{array}{l}\text { Magnification } \\
\text { Factor }\end{array}$ & $(\varepsilon=4.6) \leq(q=4.4)$ \\
\hline
\end{tabular}

ISSN No.: 232 1-3906 (Print) ISSN No.: 2321-7146 (Online) Registration No.: CHAENG/2013/51235 Periodicity: Bi-Annually 


\begin{tabular}{|c|c|c|c|}
\hline \multicolumn{4}{|c|}{ Table 2 [Continued $]$} \\
\hline & \multicolumn{3}{|c|}{ 1. Detailing for local ductility of web } \\
\hline & \multirow[t]{2}{*}{ Vertical Bars } & Provide 16mm \#@100mm c/c. & \\
\hline & & $\therefore \rho_{v}=8.74 \times 10^{-3} \geq 0.002$ & Eq. (9) satisfied. \\
\hline & \multirow{2}{*}{$\begin{array}{l}\text { Horizontal } \\
\text { Bars }\end{array}$} & Provide 8mm \#@100mm c/c. & \\
\hline & & $\therefore \rho_{h}=2.19 \times 10^{-3} \geq 0.002$ & $\begin{array}{l}\text { Eq. (10) satis- } \\
\text { fied }\end{array}$ \\
\hline & \multicolumn{3}{|c|}{ 2. Check for Diagonal Tension Failure } \\
\hline & $\begin{array}{l}\text { Design shear } \\
\text { force }\end{array}$ & $\begin{array}{l}\text { For }\left(\alpha_{s}=0.51\right)<2 \\
\left(V_{E d}=1.055 \times 10^{6} \mathrm{~N}\right)<\left(V_{R d, c}+0.75 \rho_{h} f_{y d}, h b_{w o} \alpha_{s} l_{w}=\right. \\
1.7769 \times 106 \mathrm{~N})\end{array}$ & $\begin{array}{l}\text { Eq. (12) sat- } \\
\text { isfied. Hence } \\
\text { design is safe. }\end{array}$ \\
\hline & \multicolumn{3}{|c|}{ 3. Check for Compression Failure of web } \\
\hline & $\begin{array}{l}\text { Design shear } \\
\text { force }\end{array}$ & $\left(V_{E d}=1.055 \times 10^{6} \mathrm{~N}\right)<\left(V_{R d, \max }=1.87 \times 10^{6}\right)$ & $\begin{array}{l}\text { Eq. (20) satis- } \\
\text { fied. Hence de- } \\
\text { sign is safe. }\end{array}$ \\
\hline & \multicolumn{3}{|c|}{ 4. Check for Sliding shear failure of web } \\
\hline & $\begin{array}{l}\text { Design shear } \\
\text { force }\end{array}$ & $\left(V_{E d}=1.055 \times 10^{6} N\right)<\left(V_{R d, \max }=1.87 \times 10^{6} N\right)$ & $\begin{array}{l}\text { Eq. (23) satis- } \\
\text { fied. Hence de- } \\
\text { sign is safe. }\end{array}$ \\
\hline \multirow[t]{7}{*}{$\mathrm{C}$. } & \multicolumn{3}{|c|}{ Design of Boundary elements } \\
\hline & \multirow[t]{2}{*}{ 1. Vertical Bars } & $\begin{array}{l}\text { Provide 16mm \#@100mm c/c and ISLB150 } \\
\text { is fully encased in reinforced concrete section } \\
\text { as vertical reinforcement at both boundary } \\
\text { members }\end{array}$ & \\
\hline & & $\left(\mathrm{A}_{\mathrm{s}}=1005 \mathrm{~mm}^{2}\right)>\left(0.3 \% \mathrm{~A}_{\mathrm{c}}=95.06 \mathrm{~mm}^{2}\right)$ & $\begin{array}{l}\text { Eq. (38) satis- } \\
\text { fied. }\end{array}$ \\
\hline & $\begin{array}{l}\text { 2. Horizontal } \\
\text { Bars }\end{array}$ & $\begin{array}{l}\text { Provide } 8 \mathrm{~mm} \# @ 100 \mathrm{~mm} \mathrm{c} / \mathrm{c} \text { as hoop rein- } \\
\text { forcement. }\end{array}$ & \\
\hline & $\begin{array}{l}\text { 3. Check for } \\
\text { plastic rotation }\end{array}$ & $\left(\alpha \cdot \omega_{w d}=8.47\right) \geq\left[\left(30 \cdot \mu_{0} \cdot v_{d} \cdot \varepsilon_{s y \cdot d} \cdot \frac{b_{c}}{b_{0}}-0.035\right)=1.0357\right]$ & $\begin{array}{l}\text { Eq. (38) satis- } \\
\text { fied. Hence de- } \\
\text { sign is safe. }\end{array}$ \\
\hline & $\begin{array}{l}\text { 4. Encased steel } \\
\text { profile }\end{array}$ & $\begin{array}{l}\text { Steel profile ISLB } 150 \text { is fully encased at } \\
\text { boundary elements of shear walls. }\end{array}$ & \\
\hline & $\begin{array}{l}5 . \text { Steel contri- } \\
\text { bution propor- } \\
\text { tion }\end{array}$ & $0.2 \leq\left(\delta_{1}=0.3526\right) \leq 0.9$ & $\begin{array}{l}\text { Eq. (47) satis- } \\
\text { fied. } \\
\text { Hence design is } \\
\text { safe. }\end{array}$ \\
\hline
\end{tabular}


Table 2 [Continued]

D. $\quad$ Design Resistance of headed stud shear connector

\begin{tabular}{|l|l|l|}
\hline $\begin{array}{l}\text { Shear connec- } \\
\text { tor }\end{array}$ & $\begin{array}{l}\text { Provide 13mm diameter, 25mm headed shear } \\
\text { stud connector of length 75mm @ 150mm } \\
\text { c/c spacing all through the height of the wall. }\end{array}$ & \\
\hline $\begin{array}{l}\text { Resistance two } \\
\text { failure modes } \\
\text { of headed stud } \\
\text { shear connector }\end{array}$ & Minimum $P_{R d}=24.17 \times 103 \mathrm{~N}$ & $\begin{array}{l}\text { Minimum value } \\
\text { of Eq. (49) and } \\
(50)\end{array}$ \\
\hline $\begin{array}{l}\text { No. of headed } \\
\text { stud shear } \\
\text { connector }\end{array}$ & No. of shear connector $=20.72 \approx 21$ & Eq. (55) \\
\hline
\end{tabular}

Fig. 2 represents detailing of Steel-Concrete Composite Shear Wall.

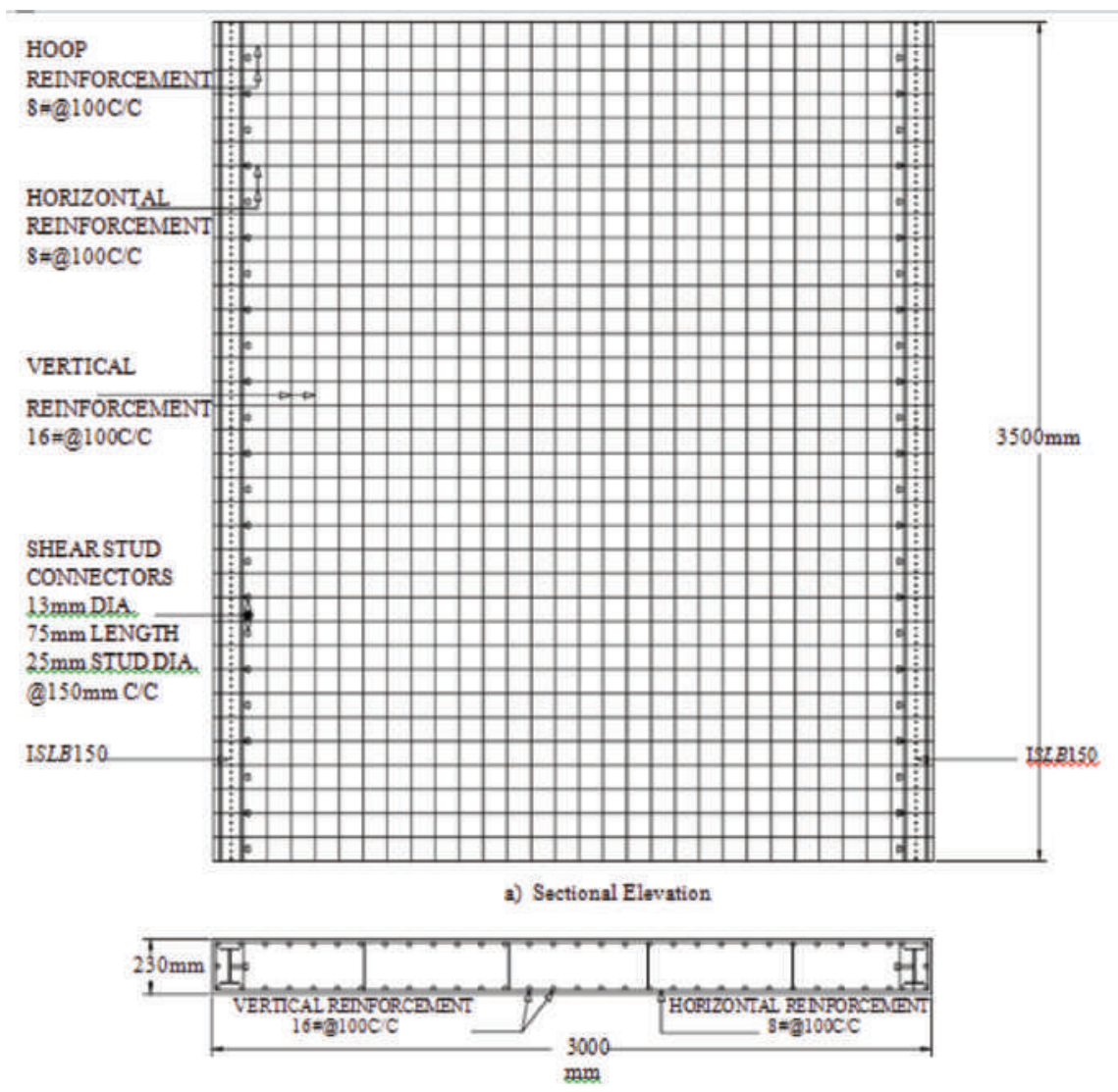

Figure 2: Detailing of steel-concrete composite shear wall 


\section{Conclusions}

A new proposed SCCMSW-frame system has been analyzed and designed as per specifications of Eurocode 2, 4 and 8. Wall panel has been designed for a flexural mode of failure considering slender wall according to EC8. Ductile detailing has been obtained for web by taking into account local ductility. Further, it has been checked against diagonal tension failure, compression failure of web and sliding failure of web. Boundary elements of shear walls have been designed as composite columns according to EC8. Shear connectors have been used for interface connections between steel section and concrete, designed as per prescription of EC2.

\section{Acknowledgement}

The authors would like to express the heartiest appreciation for all those at Shivaji University, Kolhapur who rendered help and support during this research work.

\section{References}

[1] N. M. Shirali, "Seismic resistance of a hybrid shear wall system”, Ph.D. dissertation, Institute of steel construction and fracture mechanics, Darmstadt Univ. of Technology, Iran, 2002.

[2] Eurocode 8 (EC 8), Part 3, "European committee for standardization", Design Provisions for Earthquake Resistance of Structures, Brussels, 2003.

[3] Uniform Building Code (UBC 94), "Structural engineering design provision”, International Conference of Building Officials, United States of America, 1994.

[4] S. Ramesh, M. N. Kreger, M. D. Bowman, "Design report submitted to charlus pankow foundation”, School of Civil Engg., Purdue Univ., Lafayette, Indiana, 2014.
[5] ASCE 7, "Minimum design loads for buildings and other structures", American Society of Civil Engineers, 2010.

[6] ANSI/AISC 360-10, "Specification for structural steel buildings", American Institute of Steel Construction, Chicago, Illinois, 2010.

[7] R. Junemann, C.L. Juan, M. A. Hube, J. A. Vasquez, M. F. Chaco, "Study of the damage of reinforced concrete shear walls during the 2010 Chile earthquake", The Jour. of the International Association for Earthquake Engineering, Wiley Library, 2016.

[8] Eurocode 8 (EC 8), "European committee for standardization, Design of structures for earthquake resistance - Part 1: General rules", Seismic action and Rules for Buildings, Brussels, 2004.

[9] Dan, A. Fabin, V. Stoian, "Theoretical and experimental study on composite steel-concrete shear wall with vertical steel encased profiles", Jour. of Constructional Steel Research, Elsevier, pp. 800-813, 2011.

[10] Q. Zhao and Astanesh-Asl, "Seismic behavior of composite shear wall systems and its application of smart structures technology", Jour. of Steel Structures 7, pp. 69-75, 2007.

[11] V. Stoian, D. Dan, A. Fabian, "Composite shear walls with encased profiles, New solution for buildings placed in seismic area”, Acta Technica Napocensis, Civil Engineering and Architecture, vol. 54, pp. 5-12, 2011.

[12] A. Fabian, D. Daniel, V. Stoian, I. Demeter, T. Nagy-Gyorgy and C. Florut, "Comparative study concerning the seismic behavior of composite steel-concrete structure steel encased profiles", Proceedings Fib Symposium PRAGUE, Session 5-6: Composites and Hybrids, pp. 01-06, 2011. 
[13] P. P. Phadnis, D. K. Kulkarni, A. B., Kulkarni, V. V. Karjinni, "Performance of composite steel-concrete shear walls with encased vertical steel sections", The Indian Concrete Journal, vol. 92, no. 7. pp. 74-81, 2018.

[14] Eurocode 4 (EC4), Part 1-1, "Design of composite steel and concrete structures", General Rules and Rules for Buildings, EN 1994-1-1, 1994.

[15] R. Narayanan and V. Kalyanraman, "INSDAG guide for the structural use of steelwork in building", Institute for Steel Development and Growth, 2004.

[16] K. K. Dong, "A database for composite columns”, M.S. Thesis, Georgia Institute of Technology, 2005.

[17] American Institute of steel Construction Inc., "Load and Resistance Factor Design (LRFD)”, Specification for Structural Steel Buildings, Chicago, 1986.

[18] L. G. Griffis, "Load and resistance factor design of W-shapes encased in concrete", Steel Design Guide Series, American Institute of Steel Construction, 2003.

[19] C. Walin, Z. Jianwei, D. Hongying and W. Min, "Research in seismic performance of shear wall with concrete filled steel tube columns and concealed steel trusses", Jour. of Earthquake Engineering and Engineering Vibration, vol. 10, no. 4, pp. 535-546, 2011.

[20] Design Examples, Version 15.0, Companion to the AISC steel construction manual, American Institute of Steel Construction, 2017.

[21] Eurocode 2 (EC2), "Design of concrete structures-part 1-1: General rules and rules for buildings", EN1992-1-1, 1992.

[22] IS: 456-2000, Indian Standard, "Plain and reinforced concrete-code of practice (Fourth Edition)", Bureau of Indian Standards, New Delhi. 